\title{
Statyba
}

\section{EVALUATION OF SHEAR STRESSES IN THE WEBS OF SEGMENTAL BOX-GIRDER CONCRETE BRIDGES}

\section{A. J. Notkus \& Z. Kamaitis}

To cite this article: A. J. Notkus \& Z. Kamaitis (1999) EVALUATION OF SHEAR STRESSES IN THE WEBS OF SEGMENTAL BOX-GIRDER CONCRETE BRIDGES, Statyba, 5:1, 47-52, DOI: 10.1080/13921525.1999.10531432

To link to this article: https://doi.org/10.1080/13921525.1999.10531432

曲 Published online: 26 Jul 2012.

Submit your article to this journal

Џ Article views: 325

Citing articles: 1 View citing articles 


\title{
EVALUATION OF SHEAR STRESSES IN THE WEBS OF SEGMENTAL BOX-GIRDER CONCRETE BRIDGES
}

\author{
A. J. Notkus, Z. Kamaitis
}

\section{Introduction}

Concrete box-girder bridges are most widespread bridge type today. Many prestressed box-girder bridges are constructed by balanced cantilever method. Erection of a bridge starts at piers where segments are progressively placed on each side of the pier and tied together by post-tensioning of top tendons. The bridge construction is completed by stressing the bottom cables in the span. The method of construction influences the design and structural characteristics of the cross-sections. The structural system is changed many times from statically determinate cantilever during erection up to frame or continuous beam in the final state. It brings a number of uncertainties concerning the actual state of stress of the completed structure. The additional stresses are produced in the structure during its construction. Sometimes the state of stress cannot be characterized by simple calculations. More detailed structural analysis must be used.
In many precast segmental box-girder bridges built in Lithuania intensive shear cracking in the boxgirder webs is observed (Fig 1). The first cracks in some bridges subjected only to dead load weight have been observed just after construction. Shear cracks are inclined at approximately 15-60 degree angle to the longitudinal axis of the girders. They usually appear in a zone near supports or close to midspan where minimum cross-section depth or tendon anchors are provided. Cracks develop when the principal tensile stress due to combination of service loads and restraint forces exceed the tensile strength of concrete. The possible causes of cracking in post-tensioned box girder bridges are discussed in [1,2]. Cracking may occur for a number of reasons, one of them is inefficient attention of designers to the effects caused by prestressing forces.

The bridges in question built in Lithuania were designed to meet the SNIP [3] requirements. Shear
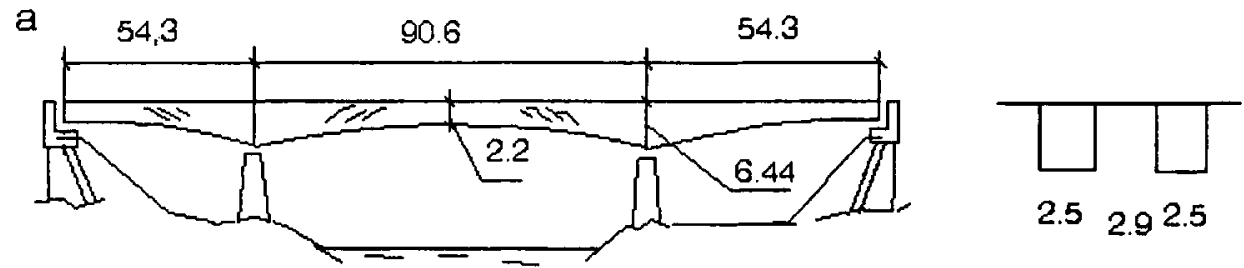

b

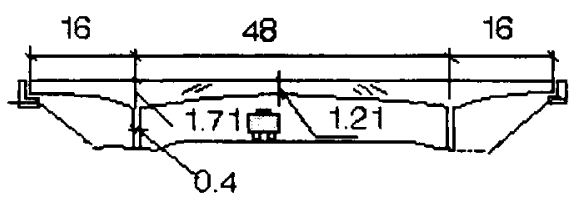

d
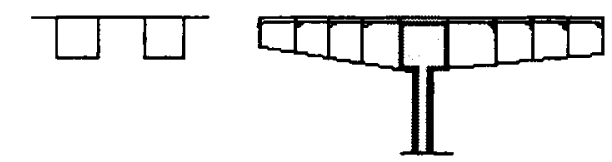

c
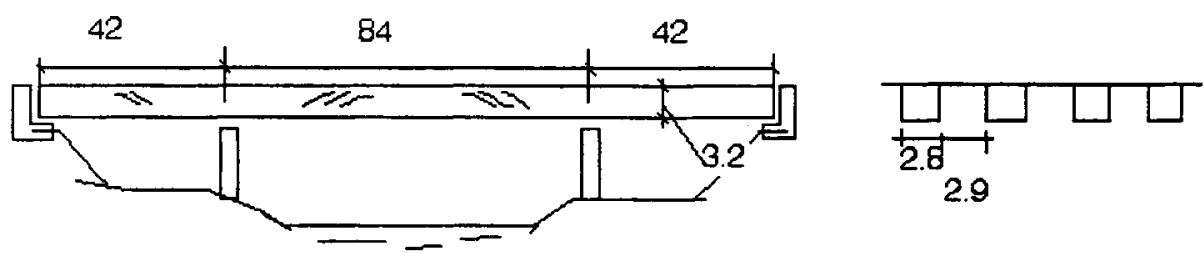

Fig 1. Cracking of prestressed concrete segmental box-girder bridges 


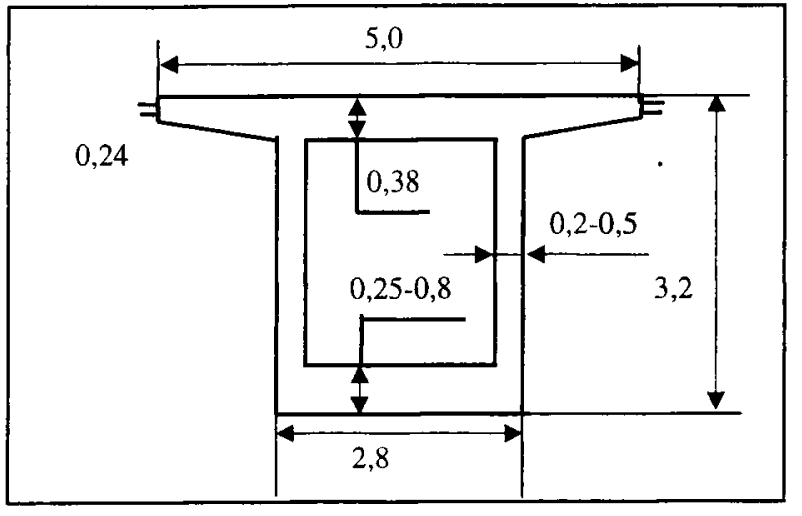

Fig 2. Cross-section of box-girder (Šilo St. bridge - Fig 1, c)

cracks are frequently found in the webs of box-girders despite the fact that calculations according to SNIP show sufficient safety margin. It was found [1] that the code provisions did not pay attention to many effects in structures. On the other hand, the analysis shows [4] that designers do not take in account the additional shearing stresses which occur in the structures during construction and prestressing of tendons. This, in summary, results in damage of bridges serious enough to be repaired.

In this article the shear cracking of box-girder segmental prestressed concrete bridges due to posttensioning forces is analyzed.

\section{Analysis of stresses in the webs using finite ele- ment method}

Recently constructed Šilo St. bridge over the river Neris was chosen for investigation of stress-strain state (Fig 1,c). We used a finite-elements method to gain a clear picture of the shear stress distribution in the webs of box-girders. The cross-section of the box-girder used in analysis is shown in Fig 2. Spatial computer model for continuous girder was prepared (Fig 3, a, b) in which actual geometry of girders, width of webs and slabs as well as variation of structural scheme from cantilever during erection up to continuous girder (after casting of slab joints and supporting girder ends on abutments) are taken in consideration. The cantilever girder was loaded by weight of segments and prestressing in upper cables while the continuous girder - by permanent load (deck, cast-in-situ joints, heating pipes, etc), prestressing in lower cables and traffic loads.
Other actions are also modelled: creep of concrete, temperature variation (dilatation and gradient). Action effects and stresses due to each of these actions and their combinations are calculated. The graphical representation of shear stresses in the webs is presented in Fig $3 \mathrm{c}$. Maximum values of obtained shear stresses in cracking zone $\tau_{z y}$ and $\tau_{\max }=\left(\sigma_{1}-\sigma_{3}\right) / 2$ due to each of mentioned actions and their combinations are presented in Table 1 and Fig $3 \mathrm{~d}$.

To avoid shear cracking in the webs, according to SNIP [3] the following two conditions shall be satisfied:

$$
\begin{gathered}
\tau_{b}=\tau_{q}+\tau_{m} \leq m_{b 6} \cdot R_{b, s h}, \\
\sigma_{1} \sigma_{1 b t, \text { ser }} \leq R_{b t, \text { ser }} .
\end{gathered}
$$

where $\tau_{q}$ is shear stress due to external load and prestress; $\tau_{m}$ is shear stress due to torsion; $R_{b, s h}$. $R_{b t, s e r}$ are flexural shear and tensile strength of concrete; $\sigma_{1}$ is principal tensile stress in concrete respectively.

\begin{tabular}{|c|c|c|c|}
\hline No & Loads, actions & $\begin{array}{l}\text { Composition of } \\
\text { combination }\end{array}$ & $\begin{array}{c}\text { Tangential } \\
\text { stresses } \\
\tau_{\mathrm{xy}} \tau_{\mathrm{max}}\end{array}$ \\
\hline \multicolumn{3}{|c|}{ Cantilevering system } & $M P a$ \\
\hline 1 & $\begin{array}{l}\text { Permanent } 1 \text {. Weight } \\
\text { of segments }\end{array}$ & 1 & $2.5 / 4.0$ \\
\hline 2 & $\begin{array}{l}\text { Prestressing of upper } \\
\text { cables }\end{array}$ & 2 & $1.5 / 9.0$ \\
\hline & Combination 1 & $1+2$ & $3.0 / 6.5$ \\
\hline \multicolumn{4}{|c|}{ System of continuous girders } \\
\hline 3 & $\begin{array}{l}\text { Permanent 2. Deck, } \\
\text { cast-in-situ, etc. }\end{array}$ & 3 & $1.2 / 1.5$ \\
\hline \multirow[t]{3}{*}{4} & $\begin{array}{l}\text { Prestressing of lower } \\
\text { cables }\end{array}$ & 4 & $1.5 / 2.5$ \\
\hline & Combination 2 & $1+2+3++4$ & $3.8 / 6.5$ \\
\hline & $\begin{array}{l}\text { Only prestressing in } \\
\text { cables Combination } 3 \\
\end{array}$ & $2+4$ & $1.5 / 9.5$ \\
\hline 5 & $\begin{array}{l}\text { Temperature gradient } \\
\text { of } 10^{\circ} \mathrm{C}\end{array}$ & 5 & $0.5 / 1$ \\
\hline \multirow[t]{3}{*}{6} & $\begin{array}{l}\text { Highway traffic load } \\
\text { AK11 }\end{array}$ & 6 & $0.5 / 0.75$ \\
\hline & Combination 4 & $1+2+3+4+5$ & $4.0 / 6.5$ \\
\hline & Combination 5 & $1+2+3+4+6$ & $4.0 / 7.0$ \\
\hline
\end{tabular}

Table 1. Maximum shear stresses in cracked zone 


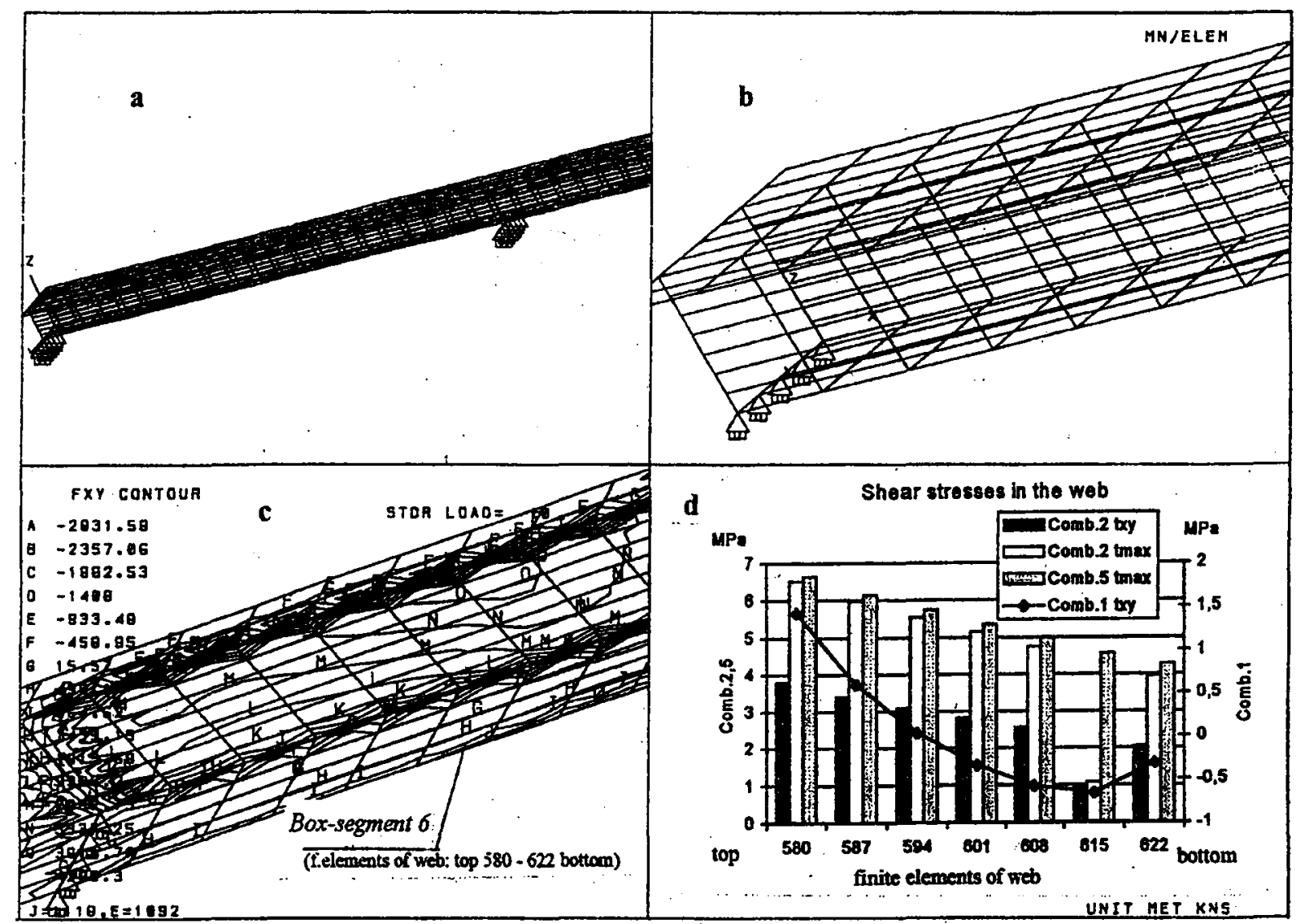

Fig 3. Design structural system of the bridge girder $(a, b)$, distribution of shear stress due to combination of actions No 5 (c), and diagram of shear stress through the web cross-section in the box-segment 6 due to combination of actions (d)

The equation for principal stresses of a point subjected to combined shear, $\tau_{x y}$, and normal, $\sigma_{x}$ and $\sigma_{y}$ stress:

$$
\sigma_{1,2}=\left(\sigma_{x}+\sigma_{y}\right) / 2 \pm \sqrt{\left(\sigma_{x}+\sigma_{y}\right) / 4+\tau_{x y}^{2}}
$$

Examination of the results predicted by finite element model and presented in Table 1 shows that the shear stresses $\tau_{\max }$ up to two times exceed the allowable limit according to condition (1) which for the bridge in question is equal to $3.5 \mathrm{MPa}$.

The calculated principle stress $\sigma_{1}$ reaches $2 \mathrm{MPa}$ and exceeds allowable value according to $\mathrm{Eq}$. (2) $\left(R_{b t, s e r}=1.5 \mathrm{MPa}\right)$. Its direction makes with horizontal an angle 15-25 degrees and approximately it corresponds to observed direction of diagonal cracks in the webs. Shear and principal stresses unavoidable propagate shearing cracks.
The large discrepancy between the predicted by finite element model shear and principal stresses and those calculated by Eq (1) and (2) are attributed to the Code provisions and imperfect design methods which do not pay attention to many effects in structures and first of all to the effect pre-tensioning in bridge girders.

In traditional direct calculations of shear stress $\tau_{q}$ through shear force $(\tau=Q \cdot S / b \cdot J)$, the influence of prestressing in lower cables on shear stress practically is not taken into account since shear force due to prestressing of these cables does not occur (Fig 4). Shear force $\mathrm{Q}$ due to horizontal forces does not develop because direction of shear stress changes within cross-section depth and their sum is equal to zero (Fig $3 \mathrm{~d} ; 6 \mathrm{c}$ ). If the moment due to prestressing of tendons $\mathrm{M}=$ const, $\mathrm{Q}=\mathrm{dM} / \mathrm{dx}=0$. 


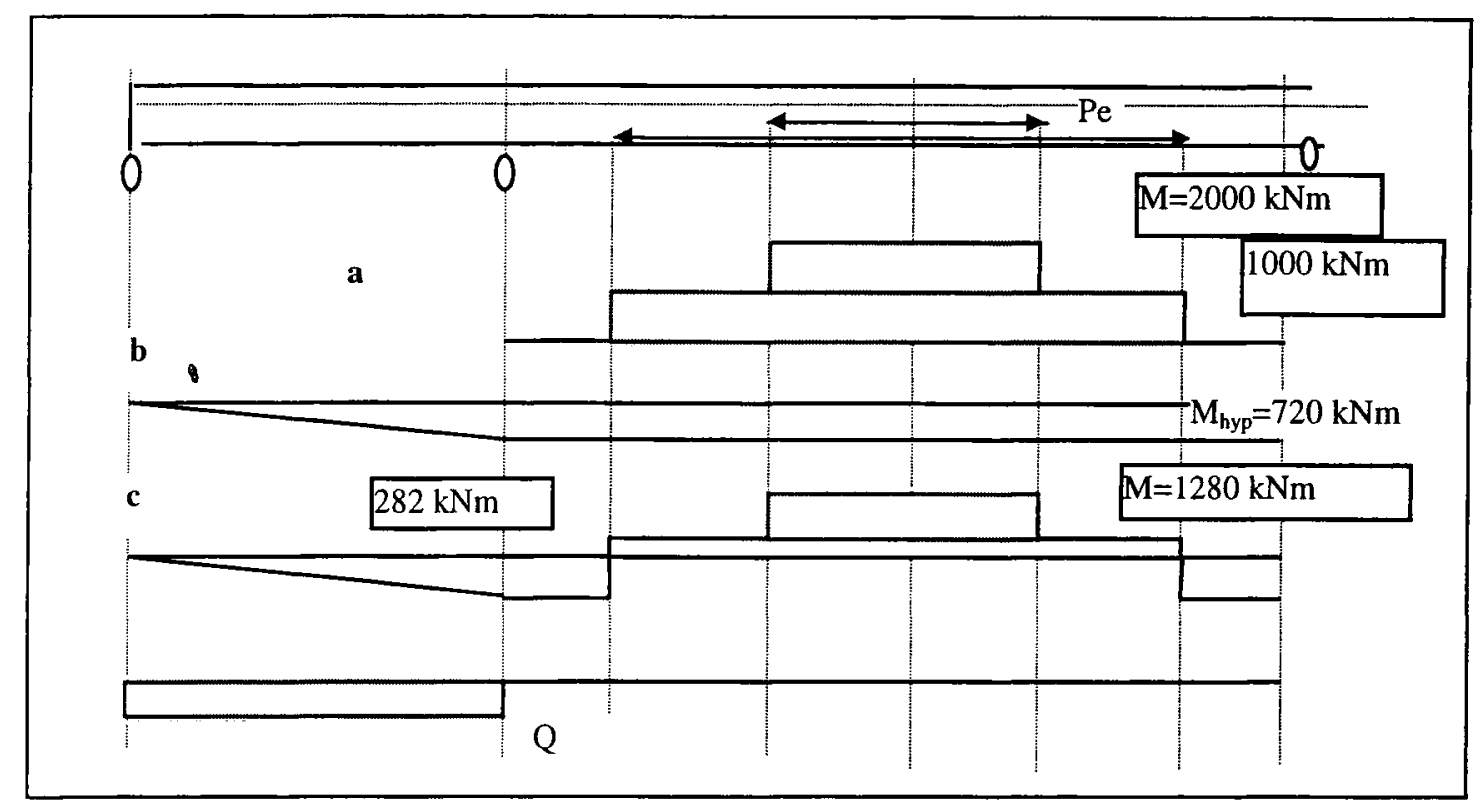

Fig 4. Residual action effects in simply supported (a) and continuous three span beam (c) due to prestressing of two cables ( $b$ - hyperstatic moments)

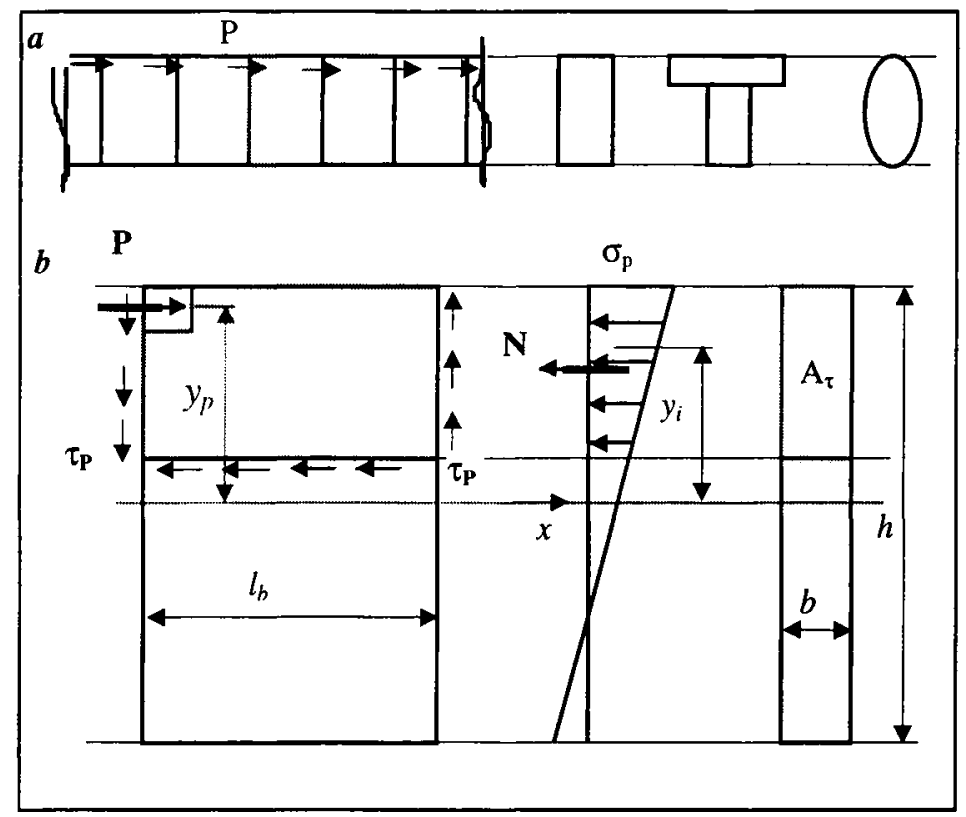

Fig 5. Prestressing forces in bridge beam (a) and stress distribution in the bridge segment due to prestressing force (b)

The analysis of temperature effects has shown [1] that additional loads can be induced by temperature gradients in bridge girders as is also shown in Table 1 (see combination No 5). While a discussion of temperature effects is outside the scope of this paper, it is important that a careful analysis be done for box-girder bridges.

\section{Shear stress due to post-tensioning forces}

If the post-tensioned force $\mathbf{P}$ is applied to the bridge segment, normal $\sigma_{P}$, and shear $\tau_{P}$ stresses are set up as shown in Fig 5 . The role which each of these two stresses plays in the behaviour of the web has not been fully understood. It is assumed that normal forces 
and shears are uniformly distributed over the thickness of the web and bending stresses to be linear distributed over the depth of segment. Normal stress $\sigma_{P}$ appears due to prestressing force $P$ acting only in this segment. Normal forces from adjacent segments are applied to the both sides of the segment in opposite directions and they are not shown in Fig $5 \mathrm{~b}$. Only the effects of straight tendons are considered, the stress concentration due to post-tensioning in the zone of anchors are not taken in consideration.

For the given stress distribution in concrete at any distance $y_{i}$ from the neutral axis, $\tau_{P}$ may be obtained from the following equilibrium equation:

$$
\sum x=0 . \quad P-N-\tau_{P} \cdot b \cdot l_{b}=0 .
$$

The horizontal force, $\mathrm{N}$, acting in segment is

$$
\mathrm{N}=? \quad N=\int \sigma_{p} \cdot d A,
$$

The value of $\sigma_{P}$ can be determined from:

$$
\sigma_{P}=\frac{P}{A} \pm \frac{M \cdot y_{i}}{J}=\frac{P}{A} \pm \frac{\left(P \cdot y_{P}\right) \cdot y_{i}}{J} \text {. }
$$

$N=\frac{P \int d A}{A} \pm \frac{P \cdot y_{P} \cdot \int y_{i} \cdot d A}{J}=\frac{P \cdot A \tau}{A} \pm \frac{P \cdot y_{P} \cdot S_{\tau}}{J}$

Substituting $\mathrm{Eq}(6)$ by $\mathrm{Eq}(4)$, we obtain:

$$
\begin{gathered}
\tau_{P}=\frac{1}{l_{b} \cdot b} \cdot(P-N)=\frac{1}{l_{b} \cdot b} \cdot\left(P-\frac{P \cdot A_{\tau}}{A}-\frac{P \cdot y_{P} \cdot S_{\tau}}{J}\right)= \\
=\frac{P}{l_{b} \cdot b} \cdot\left(1-\frac{A_{\tau}}{A}-\frac{y_{P} \cdot S_{\tau}}{J}\right) .
\end{gathered}
$$

Equation for determination the prestressinginduced shear stresses:

$$
\tau_{P}=\frac{P}{l_{b} \cdot b} \cdot\left(1-\frac{A_{\tau}}{A}-\frac{y_{P} \cdot S_{\tau}}{J}\right) .
$$

This equation indicates a variation of shear stress through the depth of the cross-section of the web.

Eq (7) can be used to predict the stress $\tau_{P}$ in the webs of all types of sections (rectangular, I and $\mathrm{T}$ shaped, circular, etc).

\section{Numerical example}

To illustrate the use of $\mathrm{Eq}(7)$, the case will be considered of I and T-shape bridge girders (Fig 6 a). a

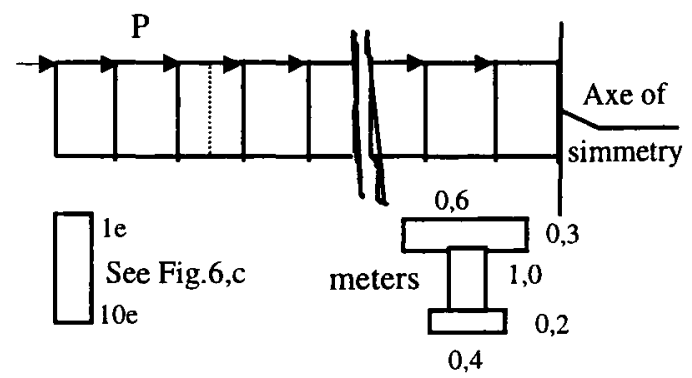

b

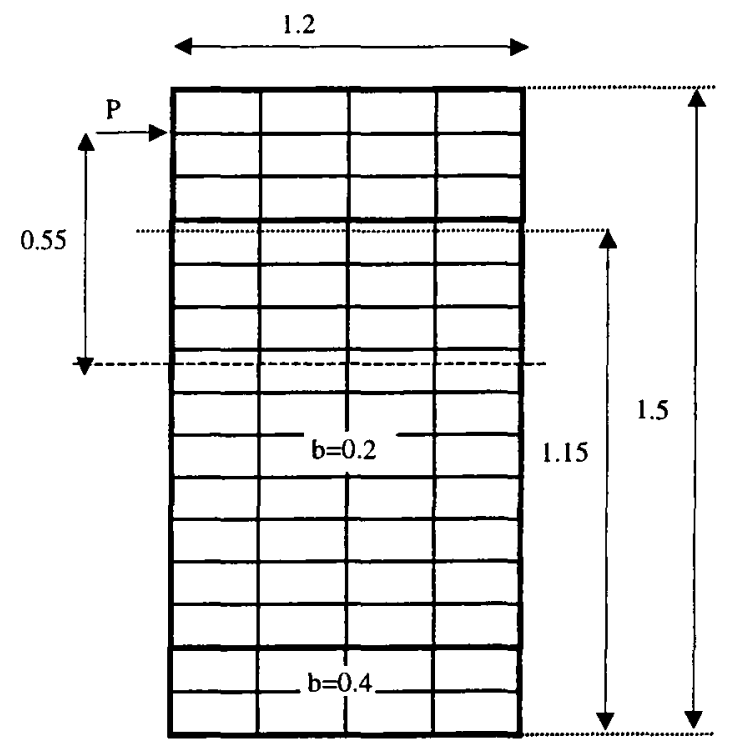

c

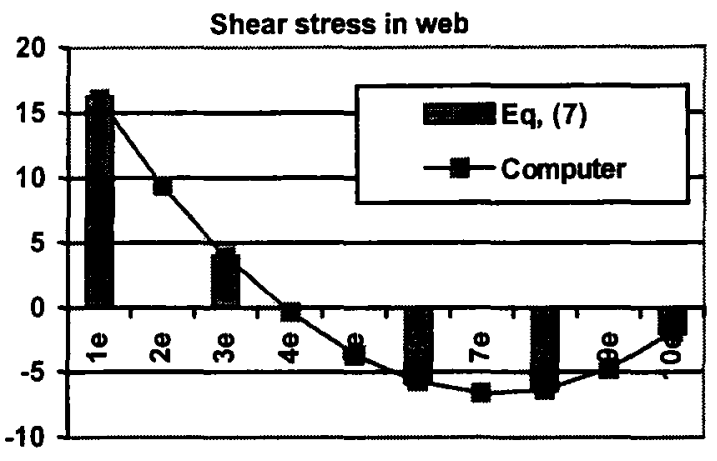

Fig 6. Bridge girder (a), FE mesh of bridge segment for T-shape (b), and shear stresses diagram for I-shape (c)

\section{Available information for T-shape girder}

Geometrical characteristics of cross-sections

$H=1,5 \mathrm{~m}, b=0,2 \mathrm{~m}, l_{b}=4 \cdot 0,3=1,2 \mathrm{~m}, A=0,46 \mathrm{~m}^{2}$, $I=0,11278 \mathrm{~m}^{4}, z_{s c}=0,85 \mathrm{~m}, y_{p}=0.55 \mathrm{~m}, A \tau=0,19 \mathrm{~m}^{2}$, $S \tau=0,09003 \mathrm{~m}^{3}$.

It is required to determine the shear stress in the section $\mathrm{y}=1.5-0.35=1.15 \mathrm{~m}$ due to prestressing force $\mathrm{P}=400 \mathrm{kN}$.

From Eq (7): 


$$
\begin{gathered}
\tau_{\mathrm{P}}=\frac{P}{l_{b} \cdot b} \cdot\left(1-\frac{A_{\tau}}{A}-\frac{y_{P} \cdot S_{\tau}}{J}\right)= \\
=\frac{400}{1,2 \cdot 0,2}\left(1-\frac{0,19}{0,46}-\frac{0,55 \cdot 0,09003}{0,11278}\right)=246,6 \mathrm{kN} / \mathrm{m}^{2} .
\end{gathered}
$$

Computer result is $\tau_{P}=245 \mathrm{kN} / \mathrm{m}^{2}$

A comparison of shear stress calculated from $\mathrm{Eq}$ (7) shows good agreement with the result obtained from computer analysis (Fig $6 \mathrm{c}$ ).

\section{Conclusions}

In box-girder statically indeterminate concrete bridges constructed by balanced cantilever method, the shear cracks in the webs are frequently found despite the fact that calculations according to SNIP show sufficient safety margin. The SNIP building code does not reflect many effects on structures. Shear cracks can occur in sections where very thin web sections are used. These cracks inevitably affect the service performance of the bridge girders.

Imperfect design methods should be considered to be the cause of cracking webs of prestressed concrete bridges and, first of all, not sufficient evaluation of effect of prestressing in statically indeterminate structures.

The finite element analysis allowed to obtain the real picture of shear stress distribution in the webs of continuous beam. Formula for predicting shear stress due to post-tensioning forces is proposed.

This investigation provides a starting point for the practical engineer to check and evaluate the posttensioning forces on the thin web design of the boxgirder bridges.

\section{References}

1. Z. Kamaitis. The causes of shear cracking in poststressed concrete box girder bridges // Statyba, No 4(8), Vilnius: Technika, 1996, p. 26-34.

2. Z. Kamaitis, A. Notkus. Šilo tilto eksploatacinių savybių analizè: Mokslo tiriamojo darbo ataskaita / VGTU. Vilnius, $1997.78 \mathrm{p}$.

3. СНИП 2.05.03-84. Мосты и трубы / Госстрой CССР. Москва, 1988. 199 c.

4. A. Notkus, Z. Kamaitis. Analysis of some design criteria for box-girder bridge decks // Civil Engineering and Environment. Proceedings. Vilnius: Technika, 1998, p. 3339.

Iteikta 19981222
TANGENTINIŲ ITEMPIU ITEMPTOJO GELŽBETONIO TILTU SIJŲ SIENELĖSE IVERTINIMAS

\author{
A. J. Notkus, Z. Kamaitis
}

S a n trauka

Daugelyje Lietuvoje ir užsienyje gembiniu-pusiausvyriniu būdu pastatytų děžinio skerspjūvio ịtemptojo gelžbetonio tiltǔ pastebetas sijų sienelių pleišejimas istrižuose pjūviuose. Šs pleišejimas negali būti paaiškintas taikant iprastus tangentiniy ir svarbiausiuju tempimo itempiy skaičiavimo metodus, nes šių itempių reikšmès nevirsija projektavimo normomis [3] ribojamu dydžiu. Buvo atlikta vieno iš neseniai pastatytų tiltų, kuriame atsirado ịstriži plyšiai dar prieš eksploatacija ( 1 c pav.), detali sijų itemptojo būvio kompiuterinè analizè [2], kurios metu buvo modeliuota reali sijų geometrija, nuolatinès ir laikinosios apkrovos, viršutiniu ir apatinių lynų itempimo jègos, temperatūros poveikiai ir ju deriniai (1 lent.). Gauta, kad koordinatiniai tangentiniai itempiai $\tau_{z y}$ (3 pav., 1 lentelè) ir ypač svarbiausieji $\tau_{\text {mux }}=$ $=\left(\sigma_{J}-\sigma_{3}\right) / 2$, pleišèjimo zonose žymiai viršija leistiną reikšmę $3,5 \mathrm{MPa}$ ir reikšmes, apskaiciuotas pagal Žuravskio formulę ( $\tau=Q \cdot S / b \cdot J$ ). Svarbiausieji tempimo itempiai $\sigma_{I}$ taip pat, nors ir mažiau, viršija leistinas reikšmes. Buvo parodyta, kad horizontalių lynų itempimo jègų sukeltas $M_{P}=$ const nesukelia skersines jégos $Q=d M / d x=0$ ( 4 pav.). Tangentinių itempiu $\tau_{\mathrm{Pxy}}$ diagrama per sienelès aukstị yra dviženkle, o itempių atstojamuju suma lygi nuliui (3, 6 pav.). Taigi Šie tangentiniai išankstinio apspaudimo itempiai negali būti apskaičiuoti per skersinę jègą Q. Šiuos įtempius siūloma skaičiuoti pagal kompiuterinius modelius, o paprastesniais atvejais pasinaudoti 5 pav. ir išraiškose (4-6) gauta formule (7), skirta tangentiniams itempiams nuo lynu itempimy jègu apskaiciuoti. Formules tinkamumas buvo patikrintas sulyginant analitines reikšmes su kompiuterinių skaičiavimu rezultatais (6 pav.). Pateikiamas tangentinių itempių skaixiavimo pavyzdys.

Algirdas Jonas NOTKUS. Doctor, Associate Professor. Civil Engineering Faculty. Vilnius Gediminas Technical University, Sauletekio al. 11, 2040 Vilnius, Lithuania.

Doctor (1979, civil engineering), Associate Professor (1982). In 1982-83 research visit to Germany. In 1990-93 a lecturer in Algeria. Author of about 50 publications. Research interests: theory of concrete strength and deformations, non-linear computer analysis, investigations and analysis of bridge structures.

Zenonas KAMAITIS. Doctor Habil, Professor. Director of International Studies Centre. Vilnius Gediminas Technical University, Sauletekio al. 11, 2040 Vilnius, Lithuania.

Doctor (1968). Expert member of Lithuanian Academy of Sciences. Author and co-author of more than 150 publications, including 6 books. Research interests: concrete structures and bridges, materials, durability, monitoring, and refurbishment. 